\title{
The Formation of The Term in The Indonesian Language Related to Covid-19 and Its Impact on The Communities Socio-Psychological Aspects
}

\author{
Sri Wahyuni* \\ Department of Indonesian Literature \\ Andalas University \\ Padang, Indonesia \\ sriwahyuni@hum.unand.ac.id
}

\author{
Ria Febrina \\ Department of Indonesian Literature \\ Andalas University \\ Padang, Indonesia \\ riafebrina@hum.unand.ac.id
}

\begin{abstract}
Many terms related to Covid-19 in Indonesia did not match the Indonesian language rules. In this study, (1) terms related to Covid-19 were described which were not by the Indonesian language rules; (2) explains the process of forming these Indonesian terms; (3) recommended these Indonesian terms that are following the rules; and (4) explains the impact on the socio-psychology of society. This study's data collection stage used the observation method with a tapping technique, the SLC-free listening technique, and the note-taking technique. Then, it followed with the data analysis stage used the intralingual matching method. The last stage was presenting the results of data analysis using informal methods. There were three results obtained during this study. First, it found the terms related to Covid-19 that did not comply with Indonesian language rules, such as coronavirus disease (covid-19), suspect Corona, Lockdown, Suspect, and Social Distancing. Second, this study also explained the three processes of forming Indonesian terms related to Covid-19, namely (a) complete absorption without changing terms and meanings, (b) absorption by adjusting sounds in Indonesian but not changing the meaning, and (c) absorption by changing the form and meaning because it is not per the rules of the Indonesian language. In the end, the example of terms related to Covid-19 recommended according to the rules of Indonesian were penyakit virus korona 2019 (Covid-19), penderita korona, karantina wilayah, penderita, and jaga jarak sosial. Finally, this study found that this term formation also impacted the socio-psychology of Indonesian society.
\end{abstract}

\section{Keywords - terms, Covid-19, Indonesian Language}

\section{INTRODUCTION}

Research in 2019 about the coronavirus disease (Covid19) was not limited to the fields of medicine, pharmacy, engineering, and economics. However, it was also necessary to investigate the terms in language that have emerged regarding Covid-19. From data taken in local online media in Indonesia, there were several terms related to Covid-19, such as the coronavirus, screening, droplets, rapid tests, hand sanitizers, chloroquine, work from home herd immunity.

The average Covid-19s' terms used recently were mostly English, which identified with italics words from obtained data. This writing rule was according to General Guidelines for Indonesian Spelling (Pedoman Umum Ejaan Bahasa Indonesia/PUEBI) for foreign word adaptation [1].
This term was also circulating throughout Indonesian society, from low education (never attending school) to higher education (postgraduate), toddlers to elderly adults, and unemployed people until the President of the Republic of Indonesia. The term circulation was not gradual but simultaneously appears in Indonesia, namely from the west to the east.

This term's circulation coincided with changes in Indonesian people's daily lives both economically and socially during the Covid-19 pandemic, significantly increasing the number of unemployed people (economic impact) and limiting activities outside the home (social impact). Hence, it made their communication limited to the environment around their house. Even though there were high-speed internet access and a good television network, the peoples' main priority was to survive by looking for alternative jobs, and adapting form normal living conditions to extra-ordinary one since all activities stop suddenly. This condition caused the public to not fully understand each of the terms related to Covid-19, which circulated massively and simultaneously.

Regarding this condition, the Indonesian government stakeholder did not schedule this term's socialization in a planned manner. The National Agency for Language Development and Cultivation (Badan Pengembangan dan Pembinaan Bahasa Republik Indonesia) also neither. The socialization referred to was related to the Indonesian language policy, which should be selected and sorted into usable terms. The terms must follow the Indonesian language rules, namely referring to Regulation no. 50 of 2015 regarding General Guidelines for Indonesian Language Spelling (Pedoman Umum Ejaan Bahasa Indonesia/PUEBI), Great Indonesian Language Dictionary (Kamus Besar Bahasa Indonesia/KBBI), and Indonesian Language Standard Grammar (Tata Baku Bahasa Indonesia).

Based on the rules of the Indonesian language, there are three essential bases in the absorption of foreign terms into Indonesian, namely (1) complete absorption without changing terms and meanings, (2) absorption by adjusting sounds in Indonesian but not changing the meaning, and (3) absorption by changing the form and meaning because it is not following the rules of the Indonesian language. Thus, it requires consideration in deciding an absorbed foreign word into Indonesian based on linguistic studies, starting from sound (phonology), word (morphology), sentence (syntax), and meaning (semantics). However, the Indonesian government, 
particularly the the National Agency for Language Development and Cultivation, did not take a stand regarding the use of words that were not following the Indonesian language. This government's indecisiveness undermined Indonesian as the national language. At the XI Indonesian Language Congress in 2018, it was decided that Indonesian must be used in public spaces, especially in the state language and official government language.

Data compiled from the Indonesian government's official website, such as indonesia.go.id, covid19.go.id, corona.jakarta.go.id, and bnpb-inacovid19.hub.arcgis.com, still uses a foreign form, not an absorption form, even not the adapted to the rules of the Indonesian language. This form was 'corona.' Thus, it could imply that the Republic of Indonesia's Government did not comply with the Indonesian language rules that had been established through Presidential Regulation Number 63, 2019 regarding the Use of Indonesian Language.

The regulation was enacted on September 30, 2019, in Jakarta by President Joko Widodo. This regulation came into force on promulgation, namely on September 30, 2019, in Jakarta by the Ministry of Law and Human Right, Yasonna H. Laoly. Furthermore, to publicly announce, it also registered this Presidential Regulation Number 63, 2019 regarding the Use of Indonesian Language into the State Gazette of the Republic of Indonesia, Number 180, 2019.

In the second part of Article 3 of the regulation, there was the statement that it must use the Indonesian language in statutory regulations. In that first paragraph, the statement includes word composition, sentence arrangement; writing technique; and spelling. The Indonesian language in the statutory regulations as referred to in first and second paragraph had its distinctive style characterized by clarity or clarity of understanding, straightforwardness, rigor, harmony, and compliance by legal requirements formulation and writing.

Based on these conditions, it was necessary to carry out an analysis related to the formation of appropriate terms related to Covid-19. It must adjust several terms originating from English to the rules of absorbing foreign languages into Indonesian. The contents of this study include (1) describing the terms related to Covid-19 which are not by the rules of the Indonesian language; (2) explaining the process of forming Indonesian terms related to Covid-19 per the rules; (3) recommending Indonesian terms relating to Covid-19 that are under the rules; and (4) explains the impact of the term formation on the socio-psychology of society.

Research on "Formation of The Term in Indonesian Language Related to Covid-19" has never been carried out. However, some research on the absorption of foreign terms into Indonesian has already been conducted, such as Baharmans' (2018) study [2]. His research shows that several foreign terms used in newspapers had been absorbed into Indonesian with absorption principles through adaptation, adoption, translation, and creation. Apart from that, Marnetti (2016) also conducted a study entitled "Foreign Terminology in the Riau Pos Pekanbaru Daily." [3] The results showed that the types of foreign terms and usage in the headlines in the Riau Pos daily went through a term matching process, namely 1) direct translation and 2) imaginary translation. It writes these foreign terms in italics. Susetyo (2016) also conducted research entitled "Use of English Words and Terms in the Opinion Rubric of the Kompas Newspaper." [4] Descriptively, the results of the analysis include (a) the form of absorption, (b) the use and, (c) the writing of English words and terms in the opinion rubric of the Kompas newspaper.

This research was different from all the studies above since it related to "The Formation of Indonesian Terms Relating to Covid-19". This research was essential, especially to recommend Indonesian terms related to Covid-19 to the National Agency for Language Development and Cultivation. Furthermore, there was also the expectation of bringing these recommended terms to the XII Indonesian Language Congress in 2023 in the future.

Pusat Bahasa (2007) [5] defines a term as a word or phrase used as a name or symbol and carefully expresses the meaning of a concept, process, state, or characteristic unique in the fields of science, technology, and art. In the formation, the terms need to be considered requirements in the use of Indonesian vocabulary, namely (1) the chosen term is the word or phrase that most appropriate to express the concept and does not deviate from that meaning; (2) the chosen term is the word or phrase which the shortest among the available options which have the same reference; (3) the chosen term is a word or phrase that has a positive meaning (connotation), (4) the chosen term is a word or phrase that nice to hear (euphonic); and (5) the term chosen is a word or phrase in the form according to Indonesian rules.

The formation of Indonesian terms related to Covid-19 would focus on the term formation guidelines, especially the correct Indonesian language rules regarding a word or phrase formation. Generally, it conducts the transfer of foreign terms into Indonesian through translation, absorption, or both. Kridalaksana (1985: 55) provides two mechanisms, namely (1) translating without changing the meaning of the expression; (2) borrowing the terms by adjusting the form of the expressions into Indonesian [6]. The formation process elaborated by Kridalaksana is one of the theories used to analyse the formation of Indonesian terms related to Covid19.

Besides the process of term formation above, there are other words addition derived from foreign language terms. According to Sarwoko (2007: 92), there are two mechanisms: absorbing and translating or matching [7]. Meanwhile, Finoza (2013: 48) states that it can divide Indonesian adsorbed elements into two significant groups [8]. The first group is the not fully absorbed elements into the Indonesian language, such as reshuffle and shuttle cook. It common to use these elements in the Indonesian context, but the pronunciation is still foreign. The second group is the absorbed elements, in which adjusted pronouncing and writing into Indonesian rules. With this formation process, Indonesian terms related to Covid-19 will be generated based on linguistic studies.

Concerning the formation of Indonesian terms related to Covid-19, this study also analyzed the community's social and psychological impact. This impact was measured by distributing questionnaires to the public regarding the effectiveness of using Indonesian terms related to Covid-19. 


\section{METHODS}

This research was a descriptive study. This research consisted of three stages, namely (1) the data collection stage, (2) the data analysis stage, and (3) the presentation stage of the data analysis result. At the data collection stage, data regarding terms related to Covid-19 in the form of words and phrases are tapped by recording important parts and used as research data. This technique was the primary research technique, known as the tapping technique. According to Sudaryanto (1993: 133), the data collection in this technique was conducting with tapping. Besides using primary techniques, this study's data collection also used advanced techniques, namely in the Uninvolved Conversation Observation Technique (Simak Bebas Libat Cakap/SBLC) [9]. The data collection carried out with this technique includes listening to the use of terms related to Covid-19 in the mass media, billboards, banners, and posters issued by government agencies. Furthermore, the recording technique was carried out in note-taking techniques, namely entering essential data card matters.

At the data analysis stage, the study used the equivalent method. The equivalent method is a method in which the determining tool lies outside the language and is independent of the part of the language concerned [9]. This study carried out the data analysis to prove that the terms related to Covid19 were mostly in English. Besides, this study also used the translational matching method with the basic technique of sorting the determinant elements (pilah unsur penentu/PUP) with an advanced technique in the form of an equalization link technique. The same interrelational technique (Hubung banding Menyamakan/HBS) was a data analysis technique that determines the comparability between the terms related to Covid-19 in English and Indonesian. With this technique, the analysis could obtain the terms related to Covid-19 according to the Indonesian language rules.

At the stage of presenting the data analysis, the discussion would present the formation of Indonesian terms related to Covid-19 in an informal presentation method. It also presents the results of data analysis in the form of a formulation using ordinary words or sentences. This data presentation was according to the method of presentation proposed by Sudaryanto (1993: 144) [9].

\section{RESULT AND DISCUSSION}

In the next section, it will explain and discuss several points which found during the study, includes: (1) the data regarding terms related to Covid-19 that were not by the rules of the Indonesian language, (2) the process of forming terms related to Covid-19 to conform to Indonesian language rules, and (3) the recommended terms related to Covid-19 by the rules of the Indonesian language.

\section{A. Terms Related to Covid-19 That Do Not Accord with Indonesian Language Conventions}

The study collected Covid-19 related terms from mass media, print media, online media, television media, billboards, banners, and government agencies. From the research conducted, there were several terms related to Covid-19, which comes from Indonesian and English.
From the number of collected data, there were more English terms than Indonesian terms found. This result came due to the emergence of the term originating from outside Indonesia. The World Health Organization (WHO), the international public health coordinator, also contributed by frequently provided the latest terms related to Covid-19 in English.

There were dissemination and immediate acceptance of the term established by the WHO by people worldwide. It caused the absorption of terms related to Covid-19 in English into Indonesian was challenging to control by the Indonesian language's absorption rules. The term was accepted and immediately applied to the people because it related to health and safety aspects. Thus, people tended to use the English terms related to Covid-19 generally.

The use of terms related to Covid-19 in English caused people to understand every term that appears. Moreover, these terms coincided so that people could not choose terms in the Indonesian language. They follow the development of terms related to Covid-19 in English, even though there were terms that can be understood, and there were also terms that could not be understood. There were several terms related to Covid19 that did not match the Indonesian language (Table I).

TABLE I. THE COVID-19 TERM THAT NOT MATCH IN THE RULE OF INDONESIA LANGUAGE

\begin{tabular}{|l|l|l|l|}
\hline Corona & Corona virus & Corona Virus Disease & Droplet \\
Lockdown & Suspect & 2019 (Covid-19) & Tracing \\
Test Kit & Rapid Test & Social Distancing & Screening \\
Swab Test & Genome & Suspect Corona & Viral \\
Chloroquine & Sequencing & Physical Distancing & Load \\
Herd & Hand Sanitizer & Work from Home & \\
Immunity & Local & Flattening the Curve & \\
& Transmission & & \\
& & & \\
\end{tabular}

The terms were not by the rules because it did not use the terms in the Indonesian language. The General Guidelines for Indonesian Spelling (PUEBI) explained that foreign languages must be in italics [3], and it did not appear in those terms. Also, the data indicated that those terms related to Covid-19 started with capital letters. In Indonesian language rules, capital letters were in the first letter of the name element. Meanwhile, terms related to Covid-19 were not a name element, except for the acronym for 'coronavirus disease 2019', namely Covid-19, which used capital letters following the technique of writing the name of the disease in the medical field. Therefore, the writing of terms related to Covid-19 was not by the rules of the Indonesian language.

\section{B. The Process of Forming Indonesian Terms Related to Covid-19}

In linguistic studies, terms related to Covid-19 can be absorbed through the process of forming Indonesian terms. There are three processes of forming terms in Indonesian. An explanation of the formation of Indonesian terms related to Covid-19 is as follows.

From several terms related to Covid-19, there were three processes for the formation of Indonesian terms found. The three processes were (1) complete absorption without changing terms and meanings, (2) absorption by adjusting sounds in Indonesian but not changing the meaning, and (3) 
absorption by changing form and meaning because it is not by Indonesian language rules. An explanation of the three processes is as follows.

\section{Absorption in its entirety without changing terms and meanings}

From several terms related to Covid-19, there was one wholly absorbed term without changing the term and meaning, which was 'virus.' The term is already in the Great Dictionary of Indonesian Language (Kamus Besar Bahasa Indonesia/KBBI). According to Badan Pengembangan dan Pembinaan Bahasa (2016), two meanings of 'virus' are [10]. First, 'virus' can define as microorganisms that invisible using an ordinary microscope, can only be seen using an electron microscope, and the causes and transmitters of diseases, such as smallpox, influenza, and rabies. Second, 'virus' is illegal programs inserted into the computer system via a network or diskette to spread and damage existing programs.

\section{Absorption by Adjusting the Sound in Indonesian}

Of several terms related to Covid-19, there were five absorbed terms from adjusting the Indonesian without changing the meaning, namely 'corona,' 'chloroquine,' 'social,' 'local,' and 'test.' Among the five terms, two terms are in the form of words, while the other three terms were a phrase. Two terms in the form of words were corona and chloroquine, and three terms that are part of a phrase, namely 'social' (part of the phrase 'social distancing'), 'local' (part of the phrase 'transmission'), and 'test' (part of the phrase 'test kit' and 'rapid test').

From the two forms, only terms in the form of words could be accepted as Indonesian terms related to Covid-19 because the meaning produced was the same as the meaning of the source language. Meanwhile, terms which part of the phrase could not be accepted because the meaning of the term was not similar to the meaning of the source and only had the meaning when combined with other words related to Covid19.

Two terms related to Covid-19 that could be absorbed by adjusting the Indonesian sounds were 'corona' and 'chloroquine.'

\section{a. Corona}

The term corona was a word that comes from English. Because this word was not Indonesian, it must be absorbed and adapted to Indonesian rules. In the General Guidelines for Indonesian Spelling (PUEBI), there should be an adjustment to Indonesian letters if the term in foreign languages is absorbed. The letter / $\mathrm{c} / \mathrm{in}$ front of $\mathrm{a}, \mathrm{u}, \mathrm{o}$ in foreign languages becomes the letter / k / in Indonesian. Therefore, the correct writing is korona. This absorption was similar to applying the transformation rule such coin into koin, computer becomes komputer, and cable becomes kabel.

Even so, Febrina (2020) stated that the absorption of corona into korona was not as easy as the absorption of the words coin, computer, and cable [11]. The words coin, cable, and computer do not have the same form as other Indonesian words. In the KBBI, the word korona is already in Indonesian, namely: (1) the visible circles or rings of light around celestial bodies occur due to scattered light from suspended particulate matter or dust; (2) the halo around the sun; the outer part of the sun's atmosphere [5]. Another consideration to absorb and adjust corona into korona in Indonesian was the semantic aspect.

Verhaar (1999: 385) argues that semantics was a linguistics branch that examines meaning. In the korona, it is necessary to consider the word korona as a form of homonym [12]. A homonym is a word that has the same pronunciation and spelling but has different meanings because it comes from different sources [1]. Thus, it could propose the word korona as a form of homonym.

In fact, not only at the semantic domain, it needed to analyse the acceptance of korona as a word in the Indonesian language at the syntactic study. Ramlan (1976: 57) stated that syntax was a part of grammar, which discusses the rules of word combinations into larger grammatical units in the form of phrases, clauses, sentences, and placement according to the semantic structure desired by the speaker as the basis [13]. If later people get used to using the word korona without being accompanied by the word virus, such as in a simple sentence, " Dia meninggal akibat korona He died because the corona," the word korona, already accepted at a syntactic domain.

The principle of absorption of foreign elements was another critical aspect in absorbing the word corona and forming korona in Indonesian. In replacing foreign words and expressions, language absorption could not be carried out spontaneously and based on a person's perception [5]. There must be continuity with the existing word absorption process. Absorption must consider the existing pattern. The absorbing process appeared to the pattern of the phrase 'corona virus' (Modifier-Head) into the virus korona (Head-Modifier). Commonly, the pattern that applies in the Indonesian language is the Head (core) - Modifier (explanation) or HM pattern appropriate with the Indonesian language rules.

Based on the explanation above, this study could conclude several factors support the word corona being korona in Indonesian. First, the word korona was a unique word because its meaning already exists in Indonesian. Thus, it could add a second definition to the word korona, a new type of coronavirus that emerged in 2019, and it could cause death from coughs and colds since it triggers pneumonia. This definition was only an offer and could be refined at the XII Indonesian Language Congress in 2023, especially to include a word as an entry in the KBBI.

Furthermore, the word korona could be identified as a noun because, according to Kridalaksana (2007), a word is a noun if no one can negate it [14]. The sentence, "Bukan korona penyebab kematiannya It was not corona the cause of death," was acceptable so that it could register the word korona into the Indonesian language as a noun.

Second, the word korona is euphonic or easy to hear. This word was adequate to the principles of Indonesian phonology. Changing the sound from [c] to [k] was an attempt to adjust to the Indonesian sounds. Third, the word could form other words with the rules for forming words in Indonesian. The word korona could be formed through a compounding process so that it could produce coronavirus compound words. Fourth, it did not have a negative connotation, so that Indonesian language users quickly accepted it. Fifth, it was often used. The standard often used was the frequency or how often it used and the range or widely spread. The phrase virus korona had been used frequently nowadays and was predicted to be 
used frequently in the future, and has spread widely throughout Indonesia. These five factors indicate that the word korona meets the requirements to be the entry in the KBBI.

\section{b. Chloroquine}

The term chloroquine can be absorbed into Indonesian using the rules contained in the General Guidelines for Indonesian Spelling (PUEBI). It conducted the absorption process by adjusting letters from English to letters in Indonesian. According to the Badan Pengembangan dan Pembinaan Bahasa (2016: 64), the letter /ch / in front of $a$ and $o$ in foreign languages became the letter $/ \mathrm{k} /$ in Indonesian; letter /q/ becomes /k/; it removed the letter /e/ at the end to fit the sound into Indonesian. Based on this explanation, it could absorb the form of chloroquine into Indonesian become klorokuin. The word klorokuin was already in the Great Indonesian Language Dictionary (KBBI). According to the Badan Pengembangan dan Pembinaan Bahasa (2016: 64), klorokuin is a drug for malaria (usually in the form of tablets) [10].

\section{Absorption by Changing Form and Meaning}

From the several terms related to Covid-19 above, some absorbed terms must follow by changing their form and meaning because they did not follow the Indonesian language rules. A number of these terms were corona, coronavirus, Covid-19, suspect corona, lockdown, suspect, social distancing, tracing, test kits, rapid tests, swab tests, genome sequencing, physical distancing, screening, droplets, hand sanitizers, chloroquine, work from home, herd immunity, viral load, local transmission, and flattening the curve novel. It identified that through the translation process, it could make these changes.

According to Muis, Artanti, and Sudewo (2010: 19), there are two ways to conduct the formation of Indonesian terms through terms of translation [15], namely (1) the conformity of meaning, but the form is not equivalent, and (2) the conformity of form and meaning. In the formation of Indonesian terms related to Covid-19, a translation could provide several advantages: it can enrich Indonesian vocabulary with synonyms, can improve the power of Indonesian expression, and be a solution for the Indonesian people in understanding the difficulties of using foreign terms related to Covid-19.

Based on the guidelines put forward by Muis, Artanti, and Sudewo (2010: 20), it could carry out the formation of Indonesian terms related to Covid-19 through translation in the following ways [15].

a. The translation is not based on one word but translated into one word. In the formation of Indonesian terms related to Covid-19, the examples of this non-one-word translation are as follows:

$\begin{array}{ll}\text { lockdown } & \text { karantina wilayah } \\ \text { flattening the curve novels } & \begin{array}{l}\text { pemerataan kurva penularan } \\ \text { viral load }\end{array} \\ \text { jumlah virus dalam darah }\end{array}$

b. In the positive form, the translation of the foreign terms becomes the positive term in Indonesian, as vice versa, the translation trought the negative terms into negative forms.

In the formation of Indonesian terms related to Covid-19, the example of translation based on the positive and negative forms are as follows:

$\begin{array}{ll}\text { suspect } & \text { penderita } \\ \text { suspect corona } & \text { penderita korona } \\ \text { workfrom home } & \text { bekerja dari rumah }\end{array}$

The term translation must preserve the word classes of foreign terms. In the formation of Indonesian terms related to Covid-19, the example of translation by maintaining word classes are as follows:

$\begin{array}{ll}\text { tracing } & \text { pelacakan (nomina) } \\ \text { social distancing (verba) } & \text { jaga jarak sosial (verba) } \\ \text { physical distancing (verba) } & \text { jaga jarakfisik (verba) }\end{array}$

\section{Recommended Indonesian Terms Relating to Covid-19}

Based on the formation rules, several recommended Indonesian terms were related to Covid-19, shown in Table II.

TABLE II. THE RECOMMENDED TERM IN INDONESIA RELATED TO CovID-19

\begin{tabular}{|l|l|}
\hline Terms in English & Terms in Bahasa Indonesia \\
\hline Corona virus & virus korona \\
\hline Corona virus disease 2019 (covid- & $\begin{array}{l}\text { penyakit virus korona-19 (Covid- } \\
19)\end{array}$ \\
\hline Suspect corona & penderita korona \\
\hline Lockdown & karantina wilayah \\
\hline Suspect & penderita \\
\hline Social distancing & jaga jarak sosial \\
\hline Tracing & pelacakan \\
\hline Test kit & alat uji \\
\hline Rapid test & tes cepat \\
\hline Swab test & tes usap \\
\hline Genome sequencing & pengurutan DNA \\
\hline Physical distancing & jaga jarak fisik \\
\hline Screening & penyaringan \\
\hline Droplet & tetesan \\
\hline Hand sanitizer & pembersih tangan \\
\hline Work from home & bekerja dari rumah \\
\hline Herd immunity & kekebalan kolektif \\
\hline Viral load & jumlah virus dalam darah \\
\hline Local transmission & penularan lokal \\
\hline Flattening the curve novel & pemerataan kurva penularan \\
\hline &
\end{tabular}

\section{The Socio-Psychological Impact of the Indonesian} Terms Formation Related to Covid-19

The formation of Indonesian terms related to Covid-19 had a social and psychological impact on society. This study also distributed several questionnaires to the public, asking about the effectiveness of using words associated with Covid-19, both in English and in Indonesian. From the community response, it could see that the term had a social impact. First, it was easier for people to understand Indonesian terms related to Covid-19 than English words related to Covid-19.

Second, with Indonesian terms related to Covid-19, the public could find out about the disease and risks of Covid-19 to themselves and the environment. Several established health protocols, such as wearing masks, maintaining distance, and washing hands, could be applied in everyday life for taking care of ourselves and our family. The community became dutiful and disciplined in implementing health protocols based on an understanding of Indonesian terms related to Covid-19. 
From the public response to the formation of English terms related to Covid-19, people felt that this term harms their psychology. People were filled with worry and anxiety every time they hear this term. This condition was due to their limited understanding of these English terms. However, the public could control themselves and comply with health protocols after knowing Indonesian terms related to Covid-19. Thus, people could carry out activities comfortably during the Covid-19 pandemic.

\section{CONCLUSION}

From the discussion above, several conclusions can take based on the results of this study. First, terms related to Covid19 that did not comply with Indonesian language rules were Corona, Corona Virus, Corona Virus Disease (Covid-19), Suspect Corona, Lockdown, Suspect, Social Distancing, Tracing, Test Kit, Rapid Test, Swab Test, Genome Sequencing, Physical Distancing, Screening, Droplet, Hand Sanitizer, Chloroquine, Work from Home, Herd Immunity, Viral Load, Local Transmission, and Flattening the Curve Novel. Second, there were three processes in forming Indonesian terms related to Covid-19, namely (a) complete absorption without changing terms and meanings, (b) absorption by adjusting sounds in Indonesian but not changing the meaning, and (c) absorption by changing the form and meaning because it is not by the rules of the Indonesian language. Finally, the result also recommended that the terms related to Covid-19 according to the rules of Indonesian were korona, klorokuin, virus korona, penyakit virus korona 2019 (Covid-19), penderita korona, karantina wilayah, penderita, jaga jarak sosial, pelacakan, alat uji, tes cepat, tes usap, pengurutan DNA, Jaga jarak fisik, penyaringan, tetesan, pembersih tangan, bekerja dari rumah, kekebalan kolektif, jumlah virus dalam darah, penularan lokal, and pemerataan kurva penularan. Finally, the formation of this term has a social impact on society, namely (1) the peoples can easily understand Indonesian terms related to Covid-19, and (2) the peoples can comply with health protocols based on Indonesian terms of Covid-19. Meanwhile, English terms' formation has a severe psychological impact on society, such as that people are filled with worries and anxiety every time they hear those words. However, the public can control themselves and comply with health protocols after knowing Indonesian terms related to Covid-19.

\section{ACKNOWLEDGMENT}

This research was conducted based on the research scheme of Andalas University, 2020. We gave high gratitude to the Institute of Research and Community Service (Lembaga Penelitian dan Pengabdian kepada Masyarakat/LPPM), Andalas University for the funding and support.

\section{REFERENCES}

[1] Badan Pengembangan dan Pembinaan Bahasa. "Pedoman Umum Ejaan Bahasa Indonesia." Kementerian Pendidikan dan Kebudayaan Indonesia, 2016

[2] Baharman, "Penguatan Bahasa Indonesia Melalui Penyerapan dan Pemadanan Istilah Asing pada Surat Kabar." Badan Pengembangan dan Pembinaan Bahasa, 2018.

[3] Marnetti, "Peristilahan Asing dalam Harian Riau Pos Pekanbaru." Balai Bahasa Provinsi Riau, 2016.

[4] Susetyo and Agus Milu, "Penggunaan Kata dan Istilah Bahasa Inggris pada Rubrik Opini Surat Kabar Kompas". Universitas Muhammadiyah Jember, 2016.

[5] Pusat Bahasa, "Pedoman Umum Pembentukan Istilah." Pusat Bahasa, 2007 ,

[6] H. Kridalaksana, "Pengembangan Ilmu Bahasa dan Pembinaan Bangsa." Nusa Indah, 1985.

[7] Sarwoko, "Metodologi Penelitian." Pustaka Belajar, 2005.

[8] L. Finoza, "Komposisi Bahasa Indonesia untuk Mahasiswa Nonjurusan Bahasa." Diksi Insan Mulia, 2013.

[9] Sudaryanto, "Metode dan Aneka Teknik Analisis Bahasa (Pengantar Penelitian Wahana Kebudayaan secara Linguistik)." Duta Wacana University Press, 1993.

[10] Badan Pengembangan dan Pembinaan Bahasa. "Kamus Besar Bahasa Indonesia." Kementerian Pendidikan dan Kebudayaan Indonesia, 2016.

[11] R. Febrina, "Korona atau Corona?." Retrieved from https://www.jawapos.com/opini/09/02/2020/korona-atau-corona/ on 18 Juni 2020, 15.35 WIB, 2020.

[12] J. W. M. Verhaar, "Asas-Asas Linguistik Umum." Gadjah Mada Press, 1999.

[13] Ramlan, "Ilmu Sintaksis." CV. Karyono, 1976.

[14] H. Kridalaksana, "Kelas Kata dalam Bahasa Indonesia." PT Gramedia, 2007.

[15] A. Muis and Sudewo. "Perluasan Makna Kata dan Istilah dalam Bahasa Indonesia." Pusat Bahasa, 2010. 